\title{
Mitotic indices of zooxanthellae: a comparison of techniques based on nuclear and cell division frequencies
}

\author{
B. E. Brown, N. P. Zamani
}

Department of Marine Sciences and Coastal Management, University of Newcastle upon Tyne, Newcastle upon Tyne NE1 7 RU, United Kingdom

\begin{abstract}
Hitherto, studies of mitotic indices in zooxanthellae have involved identification of doublet cells in the mitotic phase of cytokinesis. This note presents comparative results for zooxanthellae in the temperate sea anemone Anemonia viridis Forskal based upon measurements in both cytokinesis and karyokinesis, provides some evidence for the relative duration of these phases of mitosis in A. viridis zooxanthellae and highlights the potential benefits of deriving mitotic indices during karyokinesis.
\end{abstract}

Measurement of mitotic index in cell populations involves an assessment of the proportion of cells which are observed in mitosis (Mitchison 1971). Such measurements have been widely used by those monitoring growth in both animal and plant tissues, though the techniques employed have varied widely depending on the study organism, most methods calculating mitotic index on the basis of the fraction of cells showing paired nuclei or 2 mitotic figures per cell.

Studies of mitosis in symbiotic algae (zooxanthellae) resident in coelenterates have, in contrast, used an index based upon the fraction of cells appearing as doublets with a distinct cell plate (Wilkerson et al. 1983, 1987, Cook \& D'Elia 1987, Hoegh Guldberg et al. 1987, Steen \& Muscatine 1987). A major aim in these studies has been the calculation of algal population growth rates and doubling times using equations derived from phased cell division in marine phytoplankton (Weiler \& Chisholm 1976, McDuff \& Chisholm 1982, Wilkerson et al. 1983). In such a context cell plate measurements have provided reasonable estimates of in situ algal growth rates that have significantly advanced our understanding of the effects of nutrients on the dynamics of symbiotic algae (Muscatine et al. 1989); temporal patterns of algal division (Wilkerson et al. 1988); and mechanisms of algal regulation (Trench 1987)

More recently the balance between the coelenterate host and its symbiotic algae has been shown to be very sensitive to environmental factors such as temperature increase (Glynn \& D'Croz 1990), temperature decrease (Muscatine et al. 1991), salinity and irradiance (HoeghGuldberg \& Smith 1989). As a result it has been suggested (Brown 1988) that a better understanding of the mitotic cell cycle in symbiotic algae could not only lead to an improved quantitative estimate of 'stress' in coelenterates but also clarification of cause/effect relationships between mitotic responses and specific pollutants.

In the present note the advantages of monitoring mitotic indices for these purposes, using an index which is based on the number of cells showing mitotic figures, are presented using the temperate sea anemone Anemonia viridis Forskal.

Materials and methods. Anemones were collected from Millport, Isle of Cumbrae, Scotland, and were maintained under laboratory conditions as described in Suharsono \& Brown (1992) in recirculated, artificial seawater at $15^{\circ} \mathrm{C}$. The anemones were fed weekly on fresh Mytilus edulis ( $1 \mathrm{~g}$ wet weight mussel flesh per anemone).

Algal division in Anemonia viridis has previously been shown to be asynchronous (Suharsono 1990), resembling that in the temperate anemone Anthopleura elegantissima which showed considerable variability over the course of a day (Wilkerson et al. 1983). In the present experiment algal division was therefore measured over an $11 \mathrm{~h}$ period, between 09:00 and 20:00 h.

In the present experiment 2 methods of measuring mitotic index in Anemonia viridis zooxanthellae were compared - one involved identification of 2 mitotic figures per cell (using the Feulgen staining of nuclear DNA) and the other, the counting of doublet cells as used in the majority of coelenterate studies (Wilkerson 
et al. 1983). Feulgen staining of nuclear material is a standard cytochemical technique (Boon \& Drijver 1986) and one that has been used to measure nuclear division in both plants (Clowes \& Juniper 1968) and animals, including coelenterate material (Muscatine \& Neckelmann 1981).

Three tentacles were sacrificed from each of 3 anemones at hourly intervals. The tentacles were fixed in 3:1 alcohol/glacial acetic acid for $30 \mathrm{~min}$ and were then transferred to $70 \%$ alcohol and stored at $4{ }^{\circ} \mathrm{C}$.

Each tentacle was then hydrolysed in $1 \mathrm{M} \mathrm{HCl}$ at $60^{\circ} \mathrm{C}$ for $30 \mathrm{~min}$ followed by $10 \mathrm{~min}$ at $20^{\circ} \mathrm{C}$. Serial washing of tentacles in distilled water was carried out to remove any acid; tentacles were then placed in Feulgen stain for $3 \mathrm{~h}$. They were subsequently macerated on a slide in $45 \%(\mathrm{v} / \mathrm{v})$ acetic acid before being examined as a squash preparation under an Olympus phase contrast microscope at $1000 \times$ magnification.

A total of 500 zooxanthellae were counted per slide and the number of algae showing 2 mitotic figures within the cell recorded. This value was then expressed as a percentage of the total number of cells counted to provide a mitotic index based on karyokinesis (nuclear division).
Using the same tentacle samples the numbers of cells showing a cell plate were also scored and a mitotic index value calculated based on cytokinesis (cell division).

Results. In terms of measurement of mitotic index, the identification of mitotic figures proved much easier than that of cell plates. Mitotic figures could be clearly recognised in Feulgen-stained material (Fig. 1) both from the increased contrast and colour which Feulgen staining imparts to the nuclear material in the zooxanthellae. Identification of algae showing cell plates was more difficult both because the cell plate lacked any differential staining and also because any overlapping algae often gave the appearance of an 'apparent' cell plate even after repeated focussing through the depth of field of the sample (Fig. 2).

The values for mitotic indices of the zooxanthellae in karyokinesis were 3 to 5 times higher than those recorded for zooxanthellae in cytokinesis (Fig. 3).

Discussion. The higher numbers of algal cells showing mitotic figures compared with those showing cell plates may be explained in terms of the lengths of the phases of mitosis for Anemonia viridis zooxanthellae.

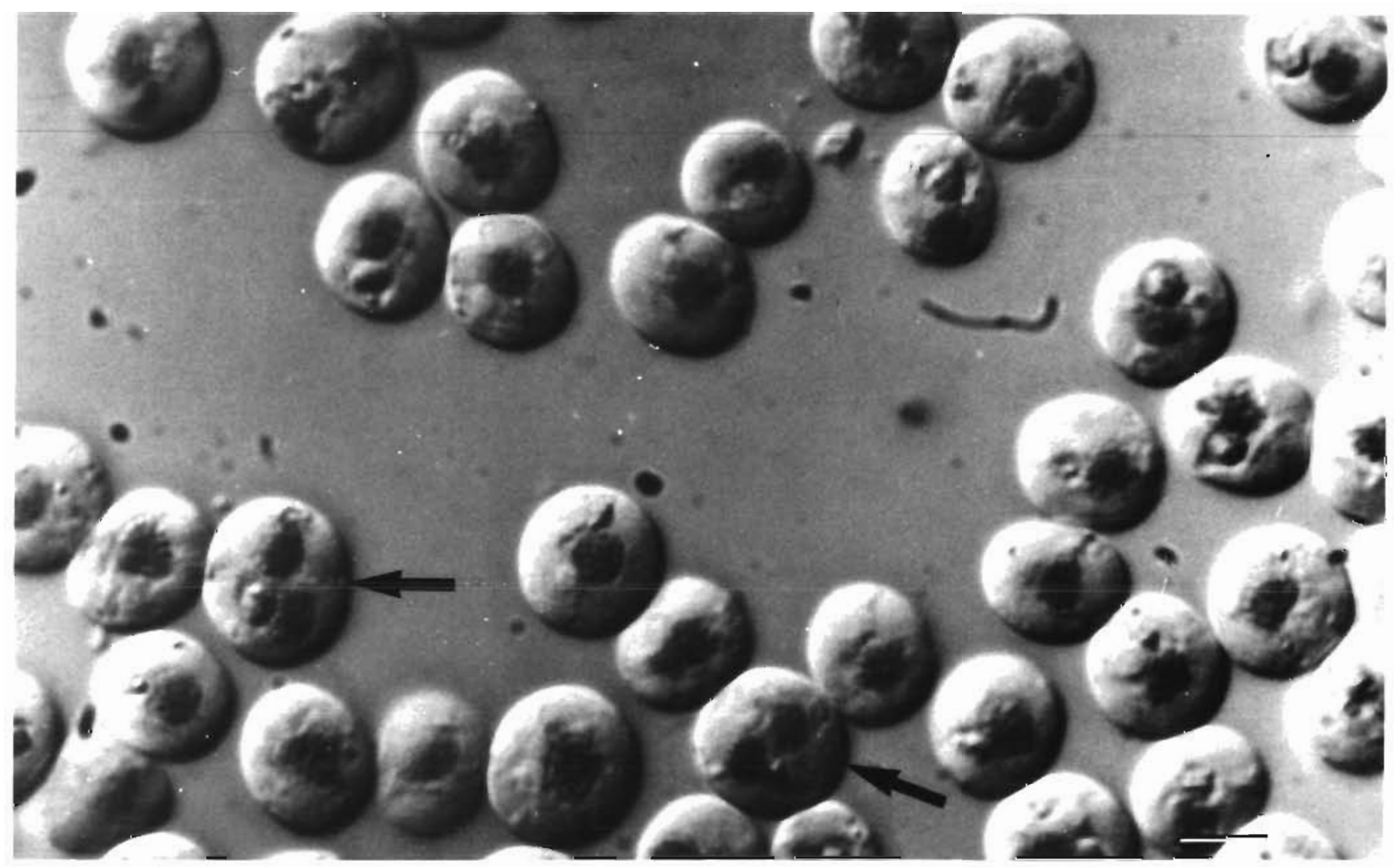

Fig. 1. Zooxanthellae in Anemonia viridis. Appearance of a tentacle squash which has been stained with Feulgen reagent to show zooxanthellae with paired mitotic figures (highlighted with an arrow). Photographed using a Nomarski interference contrast device attached to a Leitz orthoplan photomicroscope. Scale bar $=5 \mu \mathrm{m}$ 

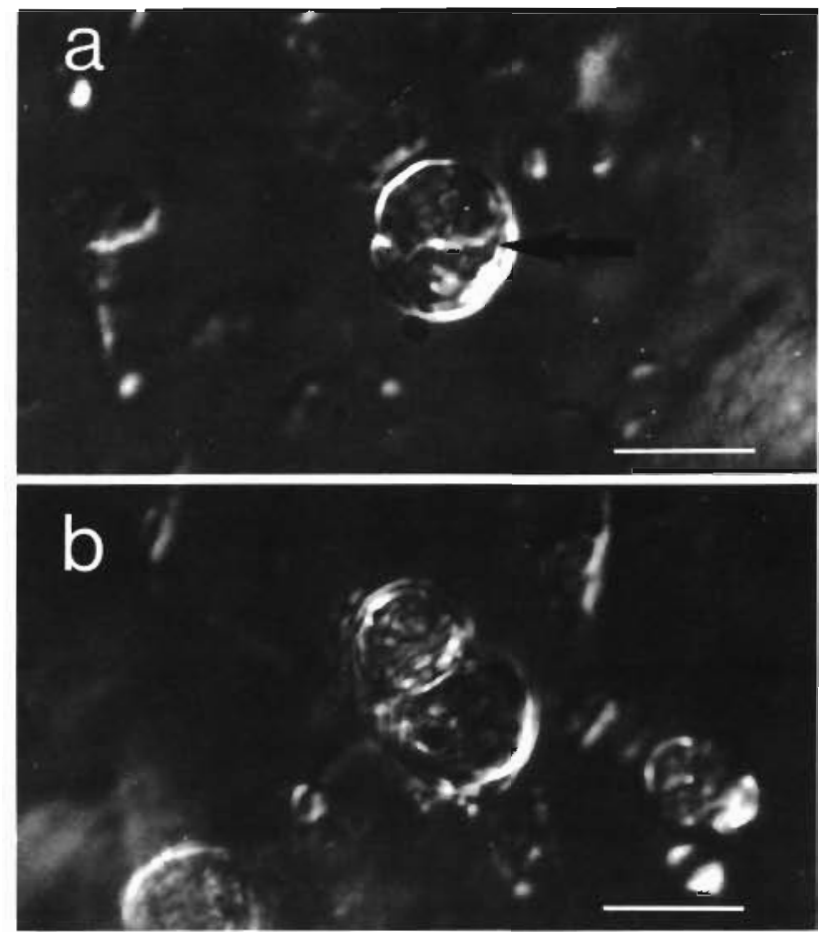

Fig. 2. Zooxanthellae in Anemonia viridis. Appearance of dividing zooxanthella in tentacle homogenate, with (a) actual cell plate highlighted with arrow and (b) a profile of 2 overlapping zooxanthellae, where identification of division status of the cell would be difficult. Photographed using a Nomarski interference contrast device attached to a Leitz orthoplan photomicroscope. Scale bars $=8 \mu \mathrm{m}$

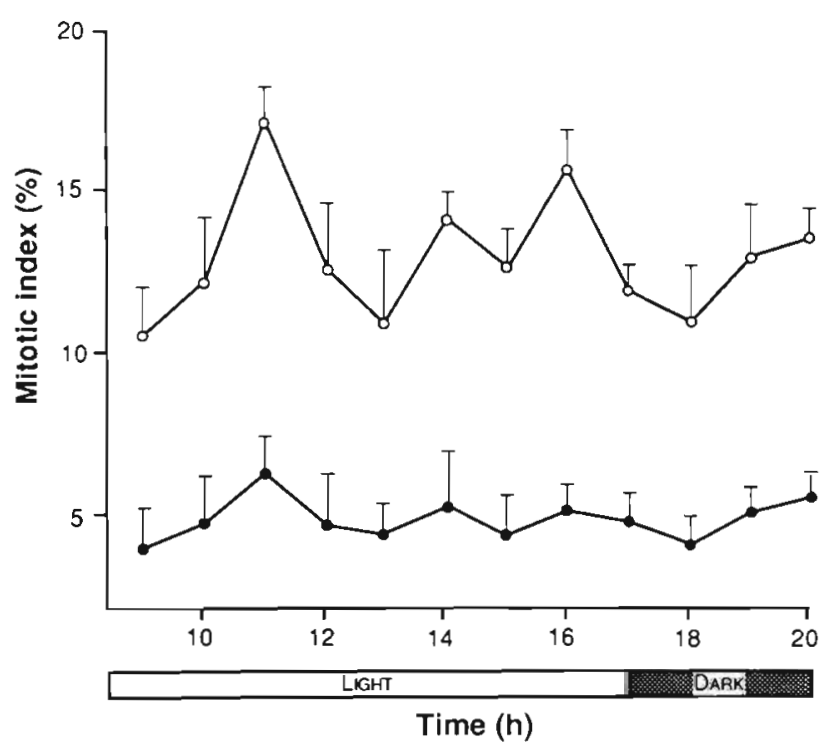

Fig. 3. Average mitotic index, expressed as paired mitotic figures $(\bullet$ and as cell plates $(\bullet)$, of zooxanthellae in the tentacles of Anemonia viridis measured hourly between 09:00 and 20:00 h. Values represent means $\pm \mathrm{SD}(\mathrm{n}=9)$
Mitotic figures appear at the end of anaphase/beginning of telophase whereas cell plate formation is a relatively short event at the end of telophase (Dyer 1976a). Since mitotic index values estimated for mitotic figures exceed those obtained for cell plates by a factor of 3 to 5 fold it can be tentatively inferred that the paired nuclei stage in $A$. viridis zooxanthellae is approximately 3 to 5 times longer than the cell plate stage.

In addition to mitotic figures being more easily identifiable than cell plates, the higher mitotic index obtained with mitotic figures would reduce counting errors, particularly where mitotic indices of zooxanthellae are low $(<1 \%$ using cell plate methods), as recorded in some tropical corals and anemones (Wilkerson et al. 1983), and/or extremely variable (Wilkerson et al. 1988). The higher visual contrast provided by stained mitotic figures also offers greater scope for automation of counts using image analysis systems. The technique could possibly be further improved by the use of nuclear DNA specific fluorescent stains, such as propidium iodide and ethidium bromide, on living material which could be examined directly.

Recent work on both tropical and temperate symbiotic coelenterates has also indicated that algal mitotic indices (expressed as paired mitotic figures) respond more sensitively to stressors such as heat-shock (Zamani 1991, Miller et al. 1992) and heavy metal ions (Nganro 1992) than mitotic indices assessed on the basis of cell plates. When Anemonia viridis were heatshocked from 15 to $28^{\circ} \mathrm{C}$ the mitotic index (paired mitotic figures) showed a significant, temporary increase of 2.5-fold compared with a small but nonsignificant change in mitotic index assessed using cell plates (Zamani 1991).

Such differences in response may be attributed to the varying susceptibility of different stages of the mitotic cycle to perturbation; for example, DNA replication apparently is particularly sensitive to increased temperature and irradiance (Brown 1976). It is also clear, mainly from work on higher plants, that mitotic division of the nucleus is not inevitably linked to cell-plate formation and cell division: either event can take place independently of the other and does so particularly under extreme environmental conditions (Dyer 1976b). Blocking of cell division but not nuclear division occurs in sea-urchin eggs as a result of exposure to heat-shock while direct damage to DNA as a result of UV-B exposure will suppress both nuclear and cell division (Ikeda 1965). Clearly a more detailed fundamental analysis of the duration of different phases of the mitotic cycles of symbiotic zooxanthellae, using a wide range of nuclear labelling techniques, could offer increased scope for highlighting the mechanisms involved in the breakdown of coelenterate symbioses under stress. 
Acknowledgements. We acknowledge financial support to N.P.Z. from the Asian Development Bank Marine Sciences Education Project. We are particularly grateful to Dr Suharsono for use of Fig. 1, to Dr M. Le Tissier and Mr R. Hewitt for photography and to Mr R. P. Dunne for critical comments on the inanuscript

\section{LITERATURE CITED}

Boon, M. E., Drijver, J. S. (1986). Routine cytological staining techniques, theoretical background and practice. Macmillan, New York

Brown, B. E. (1988). Assessing environmental impacts on coral reefs. In: Choat, J. H., et al. (eds.) Proc. 6th Int. Coral Reef Symp., Vol. 1. Sixth International Coral Reef Symposium Executive Committee, Townsville, p. 71-80

Brown, R. (1976). Significance of division in the higher plant. In: Yeoman, M. M. (ed.) Cell division in higher plants. Academic Press, London, p. 3-46

Clowes, F. A. L., Juniper, B. E. (1968). Techniques in cell research. In: Plant cells. Blackwell Scientific Publications, Oxford, p. 1-38

Cook, C. B., D'Elia, C. F. (1987). Are natural populations of zooxanthellae ever nutrient-limited? Symbiosis 4: 199-212

Dyer, A. F. (1976a). The visible events of mitotic cell division. In: Yeoman, M. M. (ed.) Cell division in higher plants. Academic Press, London, p. 49-110

Dyer, A. F. (1976b). Modification and errors of mitotic cell division in relation to differentiation. In: Yeoman, M. M. (ed.) Cell division in higher plants. Academic Press, London, p. 199-249

Glynn, P. W., D'Croz, L. D. (1990). Experimental evidence for high temperature stress as the cause of El Nino-coincident coral mortality. Coral Reefs 8: 181-191

Hoegh-Guldberg, O., McCloskey, L. R., Muscatine, L. (1987) Expulsion of zooxanthellae by symbiotic cnidarians from the Red Sea. Coral Reefs 5: 201-204

Hoegh-Guldberg, O., Smith, G. J. (1989). The effect of temperature, light and salinity on the population density and export of zooxanthellae from the reef corals Stylophora pistillata and Seriatopora hystrix. J. exp. mar. Biol. Ecol 129: 279-303

Ikeda, M. (1965). Behaviour of sulphydryl groups of sea urchin eggs under the blockage of cell division by UV and heat shock. Expl Cell Res. 40: 282-291

McDuff, R. E., Chisholm, S. W. (1982). The calculation of in situ growth rates of phytoplankton populations from frac-

This note was submitted to the editor tions of cells undergoing mitosis: a clarification. Limnol Oceanogr. 27: 783-788

Miller, D., Brown, B. E., Sharp, V A., Nganro, N. (1992) Changes in the expression of soluble proteins extracted from the symbiotic anemone Anemonia viridis accompany bleaching unduced by hyperthermia and metal stressors. J. therm. Biol 17: 217-223

Mitchison, J. M. (1971). The biology of the cell cycle. Cambridge University Press, Cambridge

Muscatine, L., Falkowski, P. G., Dubinsky, Z., Cook, P. A., Mckloskey, L.R. (1989). The effect of external nutrient resources on the population dynamics of zooxanthellae in a reef coral. Proc. R. Soc. Lond. (Ser. B) 236: 311-324

Muscatine, L., Grossman, D., Doino, J. (1991). Release of symbiotic algae by tropical sea anemones and corals after cold shock. Mar. Ecol. Prog. Ser. 77: 233-243

Muscatine, L., Neckelmann, N. (1981). Regulation of numbers of algae in the Hydra-Chlorella symbiosis. Ber. dt. bot Ges. 94: 571-582

Nganro, N. (1992). Development of a tropical marine pollution bioassay using symbiotic coelenterates. Ph.D. dissertation University of Newcastle upon Tyne

Steen, R. G., Muscatine, L. (1987). Low temperature evokes rapid exocytosis of symbiotic algae by a sea anemone. Biol. Bull. 172: 246-263

Suharsono (1990). Ecological and physiological implications of coral bleaching at Pari Island, Thousand Islands, Indonesia. Ph.D. dissertation, University of Newcastle upon Tyne

Suharsono, Brown, B. E. (1992). Comparative measurements of mitotic index in zooxanthellae from a symbiotic cnidarian subject to temperature increase. J. exp. mar. Biol. Ecol. 158: 179-188

Trench, R. K. (1987). Dinoflagellates in non-parasitic symbioses. In: Taylor, F. J. R. (ed.) The biology of dinoflagellates. Blackwell, Oxford, p. 530-570

Weiler, C. S., Chisholm, S. W (1976). Phased cell division in natural populations of marine dinoflagellates from shipboard cultures. J. exp. mar. Biol. Ecol. 25: 239-247

Wilkerson, F. P., Kobayashi, D., Muscatine, L. (1988). Mitotic index and size of symbiotic algae in Caribbean reef corals. Coral Reefs 7: 29-36

Wilkerson, F. P., Muller Parker, G., Muscatine, L. (1983). Temporal patterns of cell division in natural populations of endosymbiotic algae. Limnol. Oceanogr 28: 1009-1014

Zamani, E. P. (1991). The use of mitotic indices of zooxanthellae as a marine broassay. M.Sc. dissertation, University of Newcastle upon Tyne

Manuscript first received. June 29, 1992

Revised version accepted: October 14, 1992 